\title{
Analisis Sosiolinguistik Perubahan Bahasa Pada Masa Pra-Pasca Pubertas
}

\author{
Karlina Helmanita ${ }^{1}$
}

\begin{abstract}
Abstrak
Penelitian ini dilatarbelakangi oleh dua masalah, pertama bahasa sebagai instrumen komunikasi yang digunakan anak, dan kedua anak sebagai pengguna dan pemakai bahasa. Dari segi bahasa kita dapat amati bahwa sifat bahasa sangat dinamis dan cenderung mengalami perubahan. Sedangkan dari segi pengguna bahasa, kita juga dapat amati adanya dinamika bahasa yang terjadi pada anak secara terus menerus.

Tujuan penelitian ini adalah untuk: 1) Mengetahui perubahan bahasa anak yang mengalami masa transisi dari masa pra-pubertas ke masa pasca-pubertas awal 2) Mengetahui perubahan bahasa pada masa pascapubertas dalam pertalian antara bahasa dan pikiran; apakah bahasa yang mempengaruhi pikiran, atau pikiran yang mempengaruhi perubahan bahasa. 3) Mengetahu hubungan perubahan bahasa dengan kesantunan bahasa pada masa pra-pasca pubertas.

Penelitian ini adalah penelitian deskriptif kualitatif. Penelitian ini dilakukan melalui pengamatan terhadap fakta dan fenomena empiris yang disaksikan peneliti apa adanya. Oleh karena itu semua fenomena yang nampak, direkam dan dirinci dengan tidak mempertimbangkan benar atau salahnya. Dengan demikian penelitian ini berusaha memberikan refleksi terhadap data yang diperoleh dari objek penelitian secara langsung.

Hasil temuan penelitian ini adalah 1)Perubahan bahasa masa prapubertas mengalami peralihan karena faktor usia dan relasi yang dibangun penutur pada masa pasca pubertas. 2) Bahasa anak yang mengalami masa transisi bersifat resiprokal dengan pikirannya. Karenanya bahasa pada masa pasca pubertas dapat mempengaruhi pikiran dan pikiran juga dapat mempengaruhi perubahan bahasa seseorang.3) Kesantunan bahasa anak pada masa pasca pubertas tidak dapat dilihat melalui norma kesantunan semata tapi juga harus melihat faktor solidaritas bahasa teman-teman sebaya bagi penutur dan petutur dalam prinsip kerjasama tuturan.
\end{abstract}

Keywords: perubahan bahasa, pra-pubertas, pasca-pubertas, pikiran, kesantunan

Abstract
The research was distributed by two issues, firstly the language as an
instrument of communication that is used, and the second two children as
users and users of language. In terms of the language we can observe that
the nature of the language is very dynamic and tend to experience change.
While the language of the user, we can also observe the presence of the
dynamics of language that occur in children continuously.
The purpose of this study is to: 1) Mengetahui change language of children
who experienced the transition from the pre-puberty to the time of initial
puberty post-baby 2) know the language changes in the post-war period

${ }^{1}$ Fakultas Adab dan Humaniora, UIN Syarif Hidayatullah Jakarta 
of puberty in the nexus between language and mind; does language affect the mind, or mind affecting change language. 3) Knows the relationship with politeness language change language on pre-post puberty.

It is a qualitative descriptive study. The researchof dilwithkukan through observation of confinedap facts and empirical phenomena being witnessed by researchers. Therefore all phenomena appear, recorded and specified by not considering is right or wrong. Thus this study sought to provide a reflection against data obtained from research object directly.

The results of these research findings is 1) changes the language of the pre-puberty experience the transition because of the age factor and the relationships that were built in the post-war period speakers of puberty.) Bahasa children undergoing transition are reciprocally with his mind. Hence the language in the post-war period of puberty can affect the mind and the mind can also affect change language person. 3) Kesantunan language of the child at the time of post puberty cannot be seen through the sheer politeness norms but should also see the solidarity factor language friends-peers for the speakers and the cooperation principle in speech petutur.

\section{A. Latar Belakang}

Penelitian ini dilatarbelakangi oleh dua masalah, pertama bahasa sebagai instrumen komunikasi yang digunakan anak, dan kedua anak sebagai pengguna dan pemakai bahasa. Dari segi bahasa kita dapat amati bahwa sifat bahasa sangat dinamis dan cenderung mengalami perubahan. Sedangkan dari segi pengguna bahasa, kita juga dapat amati adanya dinamika bahasa yang terjadi pada anak secara terus menerus. ${ }^{2}$ Oleh karena itu perubahan bahasa bersifat resiprokal, terjadi secara timbal balik antara bahasa dan pemakainya. Bahasa juga merupakan produk budaya manusia yang hidupnya selalu dinamis, kreatif, dan cenderung tidak statis. Begitu pula dengan perubahan bahasa yang terjadi pada masa anak-anak, sifat resiprokal tersebut juga tidak bisa dihindarkan. Bahasa selalu akan mengalami perubahan sesuai dengan perkembangan pemikiran dan kebutuhan manusia sebagai pemakai bahasa.

Perubahan bahasa pada anak dipengaruhi oleh beberapa faktor, yaitu bertambahnya usia dan kematangan biologis, psikis, dan psikologis anak, pergaulan atau teman-teman yang dimiliki, hobi yang diminati, wawasan, ragam bacaan, dan pengetahuan yang ia peroleh. Semua hasil proses perkembangan bahasa yang dialami anak, seperti perubahan bunyi, kata, kalimat, dan makna dapat disebut sebagai perubahan bahasa. Gejala perubahan itu terjadi sebagai akibat dari perkembangan bunyi yang ia dengar atau pergeseran makna yang ia

\footnotetext{
${ }^{2}$ Ahmad Akrom Malibary, At-Taghayyur al-Dalali: Anwâ'uhu, Simâtuhu, Asbâbuhu, Asykâluhu, dalam Afâq 'Arabiyyah: Jurnal Pendidikan Bahasa Arab, Jakarta: Fakultas Ilmu Tarbiyah dan Keguruan (FITK) UIN Syarif Hidayatullah Jakarta, 2007, h. 91.
} 
peroleh dari perubahan pemakai bahasa yang ada di sekitarnya.

Perubahan bahasa pada anak, khususnya anak yang mengalami masa transisi (pubertas awal) memiliki karakteristik yang berbeda pada kanak-kanak umumnya. Berbeda karena, pertama dari segi usia, anak tersebut menjalani sebuah fase "jembatan penghubung" antara fase kanak-kanak dan orang dewasa, yakni jembatan penghubung antara masa tenang, manja dan biasa tergantung pada proteksi orang tua beralih ke masa yang penuh gejolak, bertanggung jawab dan berpikir matang secara mandiri. ${ }^{3}$ Kedua, masa ini pada sebagian masyarakat dianggap sebagai masa sturm and drung, angin topan, dan masa yang labil, ${ }^{4}$ sehingga perubahan yang terjadi pada anak usia ini, termasuk perubahan bahasanya menjadi sesuatu yang dipandang secara negatif.

Walau demikian, perubahan bahasa bisa berpengaruh negatif dan positif. Negatif karena kadang anak yang terlihat sangat sopan di rumah berubah menjadi seperti anak yang arogan; mengeluarkan kata-kata yang kurang 'santun' dan kasar. Padahal di satu sisi arogansi itu dapat dimaknai sebagai mulai munculnya keinginan anak untuk mengidentifikasi diri agar memperoleh pengakuan orang lain. Hal positif lainnya adalah kadang

\footnotetext{
${ }^{3}$ Richard M.Leaner dan Graham B. Spanier, Adolescent Development A Life-Span Perspecive, (New York: McGraw-Hill Company, 1980), h. 22.
}

bahasa yang dikemukakan anak; baik lisan maupun tulisannya lebih ilmiah, argumentatif, dan rasional dibandingkan masa sebelumnya.

Berangkat dari alasan di atas, penelitian tentang "Analisis Sosiolinguistik Perubahan Bahasa Anak Usia Pra-Pasca Pubertas dianggap perlu. Fokus penelitian adalah untuk menggali lebih jauh pengaruh perubahan bahasa terhadap perkembangan pikiran anak, khususnya anak yang mengalami masa peralihan pubertas awal, dan tingkat kesantunannya pada masyarakat atau sebaliknya. Sedangkan rumusan masalah penelitian ini adalah: 1) Bagaimana perubahan bahasa anak yang mengalami masa transisi dari masa pra-pubertas ke masa pasca-pubertas awal? 2) Bagaimana perubahan bahasa pada masa pasca-pubertas dalam pertalian antara bahasa dan pikiran; apakah bahasa yang mempengaruhi pikiran, atau pikiran yang mempengaruhi perubahan bahasa? 3) Bagaimana hubungan perubahan bahasa dengan kesantunan bahasa pada masa pra-pasca pubertas.

\section{B. METODOLOGI PENELITIAN}

Metode penelitian ini adalah penelitian deskriptif kualitatif. Penelitian ini dilakukan melalui

\footnotetext{
${ }^{4}$ Hamid Abdussalam Zahran, Ilmu Nafsin Numuwwuw, (Kairo: Dar al-Ma'arif, 1986), h. 292
} 
pengamatan terhadap fakta dan fenomena empiris yang disaksikan peneliti apa adanya. Oleh karena itu semua fenomena yang nampak, direkam dan dirinci dengan tidak mempertimbangkan benar atau salahnya. Dengan demikian penelitian ini berusaha memberikan refleksi terhadap data yang diperoleh dari objek penelitian secara langsung.

Sumber data penelitian ini adalah seorang anak berusia 11 tahun 9 bulan yaitu Nadya siswi kelas VII Madrasah Tsanawiyah Pembangunan UIN Jakarta. Karena sampel penelitian adalah anak sendiri, maka perubahan bahasanya (terutama lisan) langsung dapat diamati. Karenanya, teknik pengumpulan data diperoleh dengan dua cara yaitu mengamati dan menuliskan perubahan kata-kata atau kalimat yang diucapkan anak tersebut. Perubahan bahasa yang dicatat atau direkam adalah kata-kata yang lazim dituturkan, tapi kemudian menjadi tidak lazim diucapkan ketika anak tersebut memasuki masa pubertas awal.

\section{PEMBAHASAN}

\section{Perubahan Bahasa Pada Masa} Pra-Pasca Pubertas

Dalam kajian sosiolinguistik,
perubahan bahasa dikemukakan
dengan dua mainstream; Pertama,

${ }^{5}$ Ronald Wardhaugh, An Introduction to Sociolinguistics (Victoria: Blackwell Publishing, 2006), h. 191.

${ }^{6}$ Ibid., h. 197. berdasarkan pandangan tradisional, dan kedua berdasarkan pandangan modern. Dalam pandangan Wardhaugh, kelompok pertama diwakili oleh Ferdinand De Saussure dan Bloomfield yang berpendapat bahwa perubahan bahasa terjadi karena sebab perbedaan struktur melalui proses waktu yang sangat lama. Oleh karena itu jika terjadi perubahan bahasa, prosesnya terjadi karena faktor internal dan lebih disebabkan karena faktor-faktor yang bersifat struktural. ${ }^{5}$ Berbeda dengan pandangan tradisional, para linguis modern, yang diwakili oleh Wardhaugh ${ }^{6}$ dan Holmes ${ }^{7}$---ahli sosiolinguistk--berpendapat bahwa perubahan bahasa terjadi karena adanya faktor internal dan eksternal. Perubahan internal terjadi dari dalam bahasa itu sendiri, seperti berubahnya sistem fonologi, morfologi, sintaksis, atau tataran lainnya. Sedangkan perubahan eksternal merupakan perubahan bahasa akibat adanya pengaruh dari luar, seperti peminjaman atau penyerapan unsur bahasa (kosa kata) lain. Selain karena alasan peminjaman bahasa dan imposition, perubahan eksternal terjadi karena adanya perbedaan kelas sosial, ekonomi, batas wilayah, usia, dan jender.

Pandangan Wardhaugh dan Holmes di atas juga terjadi pada masa perubahan bahasa pra-pubertas menuju

\footnotetext{
${ }^{7}$ Janet Holmes, An Introduction to Sociolinguistics (London and New York: Longman. 1994), h. 210-229.
} 
pasca pubertas. Kata beik/abbaik yang berakar kata labbaik merupakan serapan dari bahasa Arab yang ditututrkan karena pengaruh eksternal setelah terjadinya asimilasi budaya Arab saat melakukan kontak masyarakat di nusantara, termasuk pada budaya melayu dan betawi. Dalam kasus Nadya kata "Beik/Abbaik (labbaik)" adalah ungkapan yang digunakan anggota keluarga untuk menjawab panggilan dari anggota keluarga yang lain. Sekalipun ungkapan ini tidak menjadi peraturan yang mesti ditaati, ungkapan ini secara konvensional digunakan dalam tindak tutur keluarga. Kalimat ini mengandung pengertian "ya". Misal bila salah satu dari anggota keluarga dipanggil:

Ibu : Nadya...

Nadya : Beik nda

Ayah : Bun...

Ibu : Beik yah

Kalimat ini dipengaruhi oleh bahasa Arab, yang sebagian besar digunakan dalam masyarakat keturunan Betawi. Sebagai anak yang hidup dalam lingkungan keluarga besar Betawi dan tinggal di lingkungan komunitas Betawi, ungkapan ini menjadi tidak asing bagi Nadya.

Menginjak usia peralihan ke masa remaja awal, ungkapan Beik/abbaik/labbaik, dalam beberapa situasi, berubah menjadi ya/ya apa/ha.. apa? Ungkapan tersebut diucapkan Nadya ketika menjawab sebuah panggilan yang dilakukan oleh orang tua, adik, pembantu, atau teman sebaya.

Bila dalam kasus Nadya,
perubahan bahasa dalam kata
Beik/abbaik/labbaik menjadi ya/ya
apa/ha.. apa? terjadi dalam unsur semantik ketika terjadinya masa peralihan dari pra pubertas menuju pasca pubertas awal, maka penelitian Zeller juga membuktikan perubahan bahasa yang terjada karena faktor usia). ${ }^{8}$ Perbedaannya dengan penelitian ini adalah, Zeller menemukan perubahan bunyi bahasa saat mendengar banyak penutur melapalkan kata-kata seperi haggle dan bag dengan ritme Hegel dan beg, dan bang seperti benk di sekitar wilayah Milwaukee, Wisconsin. Penutur bahasa yang lebih muda--laki-laki dan perempuan--- cenderung menghilangkan bunyi vowel pada beberapa kata. Uniknya, dalam kasus penelitian ini perubahan bunyi pada kata abbaik/beik/labbaik mengalami perubahan melalui proses peralihan kata serapan Arab yang perlahan bergeser dan bahkan beralih pada tuturan bahasa pertama tanpa membunyikan atau menghilangkan bunyi kata serapan Arab di atas. Dengan kata lain perubahan bunyi

\footnotetext{
${ }^{8}$ Zeller, C, The Investigation of a Sound Change in Change in Progress. Journal of English Linguistics, 25 (2), h.142-55.
} 
tidak saja terjadi pada peralihan bunyi vowel semata, tapi juga kata.

Namun, dalam kasus penelitian yang berbeda Eckert menemukan bahwa penambahan usia berkorelasi dengan meningkatnya konservatisme seseorang dalam berbicara. Hal itu juga menjadi ambigu; apakah pola-pola bahasa dalam masyarakat berubah sepanjang waktu atau apakah penutur menjadi lebih konservatif karena bertambahnya usia-atau karena alasan keduanya. Tanpa bukti, tidak ada cara untuk membuktikan apakah usia benarbenar dapat dijadikan patokan bahwa pola-pola dari variasi bahasa mengalami perubahan. ${ }^{9}$

Dari hasil penelitian Zeller dan Eckert di atas, perbedaan usia menentukan terjadinya perubahan bahasa. Namun demikian, menurut Wardhaugh hasil penelitian tersebut tidak dapat digeneralisir, karena pada situasi tertentu usia dapat saja menjadi faktor dominan, tetapi pada situasi yang lain ada faktor lain yang lebih dominan. Walau demikian, Wardhaugh melihat bahwa segala sesuatu yang kita lihat sebagai perubahan bahasa karena antara orang tua dan orang muda mengatakan sesuatu dengan cara yang berbeda. "Orang yang lebih tua mengatakan sesuatu dan orang yang lebih muda juga mengatakan sesuatu, bukan

Perubahan Penggunaan Pronomina

${ }^{9}$ Eckert, P., Adolescent Social Structure and the Spread of Linguistics Change, Journal Language in Society, 17, 1988, h. 153, dan dalam Ronald Wardhaugh, Op.Cit., h. 197. semata karena fenomena dari perbedaan usia."

\section{Cara Terjadinya Perubahan Bahasa Pra-Pasca Pubertas}

Menurut Holmes, perubahan bahasa terjadi melalui 3 (tiga) cara. Pertama penyebaran dari satu kelompok masyarakat ke kelompok lain (from group to group). Semakin luas jaringan sosial penutur bahasa maka perubahan bahasa juga semakin menyebar. ${ }^{10}$ Kedua, dari gaya bahasa ke gaya bahasa lain (from style to style)..Ketiga, perubahan bahasa dapat terjadi melalui 'penyebaran' (diffusion). ${ }^{11}$ Bila mengacu pada teori Holmes tentang lexical diffusion, teori ini menjelaskan bahwa perubahan bunyi tidak hanya dapat menyebar melalui proses peralihan satu kelompok ke kelompok lain atau dari satu gaya bahasa ke gaya bahasa lain, melainkan juga dapat melalui penyebaran dari satu kata ke kata lain (from word to word). Dalam konsep lain Wardhaugh menyebut proses penyebaran ini dengan sebutan konsep 'gelombang' (wave). ${ }^{12}$

Dalam kasus ini, perubahan bahasa pra pubertas-pasca pubertas awal terlihat pada perubahan gaya bahasa dalam penggunaan pronomina tuturan Nadya berikut ini:

\footnotetext{
${ }^{10}$ Janet Holmes, An Introduction to Linguistics (London and New York: Longman. 1994), h. 218-219.

${ }^{11}$ Ibid., h. 222.

12 Ronald Wardhaugh, Op.Cit., h. 193
} 


\begin{tabular}{|c|c|}
\hline $\begin{array}{c}\text { Bahasa Awal } \\
\text { (pra pubertas) }\end{array}$ & $\begin{array}{c}\text { Perubahan Bahasa } \\
\text { (pasca pubertas awal) }\end{array}$ \\
\hline Kakak sudah bilang, hati-hati dong dek & Aku udah bilang, kamu hati-hati dong \\
\hline Kakak duluan ya dek & Shemil, aku duluan \\
\hline
\end{tabular}

Dari tabel di atas, terlihat perubahan bahasa dalam menggunakan pronomina dari masa pra pubertas dan pasca pubertas awal. Pada masa pra pubertas, Nadya menggunakan pronomina sapaan diri yaitu kata "kakak" untuk sebutan orang pertama. Sementara pada pasca pubertas awal, Nadya menggunakan pronomina "aku" sebagai orang pertama secara langsung.

Adanya perubahan bahasa dalam menggunakan pronomina dalam konteks Holmes, dapat juga terjadi pada konteks tuturan Nadya. Gaya bahasa yang dituturkan oleh Nadya kepada kepada yang lain dapat juga mempengaruhi terjadinya perubahan bahasa. Termasuk ketika gaya bahasa masa pubertas awal mengalami peralihan penggunaan pronomina

Orang seringkali dan suka meniru gaya bahasa orang lain. Bila pada masa pra pubertas, interaksi sosial seseorang masih terbatas pada lingkungan keluarga, maka dengan bertambahnya usia interaksi sosial seseorang menjadi lebih luas dalam menemukan, mendengarkan, dan menirukan gaya bahasa orang lain. Peniruan gaya bahasa ini biasa dilakukan karena beberapa alasan, diantaranya untuk ingin mendapat pengakuan atau prestise yang sama dari orang yang ditiru.
Dalam kasus penelitian ini, perubahan gaya bahasa dalam penggunaan pronomina masa prapasca pubertas juga mengalami proses penyebaran melalui sistem gelombang Wardhaugh di atas. Hal ini dapat terjadi karena faktor-faktor sosial seperti usia, status, jenis kelamin, dan wilayah tempat tinggal penutur. Faktor ini memberi kontribusi bagi terjadinya perubahan bahasa dengan cepat.

Denga demikian perubahan bahasa dapat terjadi melalui salah satu atau lebih dari tiga cara Holmes di atas. Proses perubahan bahasa dapat terjadi setiap saat. Jika kita percaya bahwa perubahan bahasa dapat berubah setiap saat, maka perubahan bahasa yang sedang berlangsung (in progress) seharusnya juga dapat diamati, baik pada bahasa tuturan maupun bahasa tulisan.

\section{Bahasa dan Pikiran Pra-Pasca} Pubertas

Sejak muncul hipotesis SapirWhorf tentang linguistic determination (bahasa menentukan pikiran) kontroversi mengenai hakikat bahasa dan pikiran kian semakin marak. Perdebatan para ahli seputar tentang apakah bahasa mempengaruhi pikiran, apakah pikiran yang mempengaruhi bahasa, atau bahasa dan pikiran saling mempengaruhi satu 
sama lain. Perdebatan tersebut mengundang dua kelompok besar yaitu yang setuju pada hipotesis Sapir-Whorf dan kelompok yang kontra dengan hipotesis tersebut. ${ }^{13}$

Hipotesis Whorf menunjukkan bahwa bahasa dan pikiran itu sangat bertalian dan berhubungan. Bahasa bukan hanya sebagai alat untuk menyuarakan ide tetapi juga merupakan pembentuk ide, pemprogram kegiatan mental dan penentu struktur mental penuturnya, seperti tuturan anak masa prapubertas dan pasca pubertas dalam bagan berikut ini:

\begin{tabular}{|c|c|}
\hline \multicolumn{2}{|c|}{ Bahasa dan Pikiran } \\
\hline $\begin{array}{l}\text { Bahasa Awal } \\
\text { (pra pubertas) }\end{array}$ & $\begin{array}{c}\text { Perubahan Bahasa } \\
(\text { pasca pubertas awal) }\end{array}$ \\
\hline $\begin{array}{c}\text { Dek makannya jangan banyak-banyak, kalo } \\
\text { kegemukan nggak cantik dek }\end{array}$ & $\begin{array}{l}\text { Shemil! makannya jangan banyak-banyak, } \\
\text { kamu udah overweight, jelek lo dek Shemil! }\end{array}$ \\
\hline $\begin{array}{l}\text { Nda, kakak takut kalau ayah merokok terus, nanti } \\
\text { ayah sakit }\end{array}$ & $\begin{array}{c}\text { Nda, Nadya takut kalau ayah merokok terus, } \\
\text { paru-parunya rusak sehingga ayah sakit }\end{array}$ \\
\hline
\end{tabular}

Bentuk tingkah laku verbal di atas, telah menunjukkan adanya pertalian antara bahasa dan pikiran pra pubertas dan pasca pubertas awal. Pada tuturan ketika menyatakan perintah pada ujaran pra pubertas "Dek makannya jangan banyakbanyak, kalo kegemukan nggak cantik dek", menunjukkan pikiran mempengaruhi bahasa dan bahasa mempengaruhi pikiran bahwa kegemukan mengandung konsepsi negatif dalam konvensi bahasa tentang makna dari sebuah kecantikan. Begitu pula pada pernyataan pada ujaran "Nda, kakak takut kalau ayah merokok terus, nanti ayah sakit." Konsep penutur mengenai kesehatan dan pertaliannya dengan rokok masih sederhana, namun demikan bahasa verbal yang dituturkan menggambarkan pikiran

${ }^{13}$ International Linguistics Community On Line, The Sapir-Whorf Hypothesis, diakses 29 Maret 2013. karena telah terbangun dalam kognisi sosial penutur tentang makna kesehatan tersebut. Hubungan antara pikiran dan bahasa semakin matang dan terlihat ketika meningkatnya usia penutur dari pra pubertas sampai pasca pubertas. Konsep kecantikan dan kesehatan dalam tingkah laku verbal penutur semakin kritis dengan pernyataan argumentatif dan kritis. Perubahan bahasa terjadi dengan kian bertambahnya usia dan semakin berkembangnya penyebaran leksikal dari masa peralihan pra menuju pasca pubertas, seperti pernyataan pada ucapan "Nda, kakak takut kalau ayah merokok terus, nanti ayah sakit" menjadi tuturan "Nda, Nadya takut kalau ayah merokok terus, paruparunya rusak sehingga ayah sakit". Di sini terlihat bahwa bahasa 
senantiasa mempengaruhi pikiran seseorang.

Karenanya dalam konsep behaviorisme Skinner (1957) pikiran tidak saja merupakan bentuk dari tingkah laku non-verbal tapi juga verbal. Bahasa penting bagi pikiran. Kita berbahasa untuk mengembangkan pikiran. Pikiran ibarat tingkah laku dari berbahasa itu sendiri. Orang dapat berpikir karena ada bahasa. Itu artinya bahasa mempengaruhi pikiran. Begitu pula sistem bahasa dengan peraturan dan kosakatanya sangat penting bagi pikiran.

\section{Kesantunan Bahasa Pra-}

\section{Pasca Pubertas}

Teori kesantunan pertama kali diperkenalkan oleh Erving Goffman tahun 1967 melalui konsep "muka" (face). Konsep ini kemudian dikembangkan oleh Brown and Levinson tahun 1978 yang menjelaskan definisi "muka" sebagai the public self-image that every member wants to claim for himself (citra diri publik bahwa setiap orang ingin dihargai dirinya). ${ }^{14}$ Teori kesantunan ini juga berhubungan dengan teori tindak tutur (speech act) yang diformulasi dari John Searle yang menyatakan secara tidak

\footnotetext{
${ }^{14}$ Penelope Brown and Stephen C. Levinson, Politeness: Some Universals in Language Usage, (Cambridge: Cambridge University, 1978), h. 61.

${ }^{15}$ John R. Searle, Speech Acts: An Essay in the Philosophy of Language, Cambridge: Cambridge University, 1969, h. 24.
}

langsung bahwa kesantunan berbahasa digunakan tidak hanya untuk menggambarkan dunia, tetapi juga untuk melakukan tindakan yang dapat diindikasikan dari tampilan ujaran itu sendiri. ${ }^{15}$

Menurut Muslich, kesantunan (politeness), kesopansantunan itu adalah tatacara, adat, atau kebiasaan yang berlaku dalam masyarakat. Kesantunan merupakan aturan perilaku yang ditetapkan dan disepakati bersama oleh suatu masyarakat tertentu sehingga kesantunan sekaligus menjadi prasyarat yang disepakati oleh perilaku sosial. Oleh karena itu, kesantunan ini biasa disebut "tatakrama", dan kesantunan berbahasa tercermin dalam tatacara komunikasi lewat tanda verbal atau tata cara berbahasa. ${ }^{16}$

Berdasarkan pandangan linguis di atas, maka kesantunan menjadi bagian dari tindak tutur dalam berbahasa. Ketika terjadinya perubahan bahasa pada masa pra pubertas sampai pasca pubertas awal, maka kesantunan berbahasa menjadi bagian dari perubahan bahasa itu sendiri. Lihat tabel kesantunan berikut ini:

\footnotetext{
${ }^{16}$ Masnur Muslich, "Kesantunan Berbahasa: Sebuah Kajian Sosiolinguistik", http://researchengines.com/1006masnur2.html, diunduh tanggal 29 Juli 2009.
} 
Kesantunan Berbahasa

Perubahan masa pra pubertas dan pasca pubertas awal

\begin{tabular}{|c|c|c|c|}
\hline No & $\begin{array}{c}\text { Bahasa Awal } \\
\text { (pra pubertas) }\end{array}$ & $\begin{array}{c}\text { Pevel } \\
\text { Kesantun } \\
\text { an }\end{array}$ \\
\hline 1 & Beik/Abbaik (labbaik) & Ya.. /ya ...apa /ya..ha.... & 1 \\
\hline 2 & $\begin{array}{c}\text { Kakak sudah bilang, hati- } \\
\text { hati dong dek }\end{array}$ & Aku udah bilang, kamu hati-hati dong & 1 \\
\hline 3 & Kakak duluan ya dek & Shemil, aku duluan & 2 \\
\hline 4 & $\begin{array}{c}\text { Dek makannya jangan } \\
\text { banyak-banyak, kalo } \\
\text { kegemukan nggak cantik } \\
\text { dek. }\end{array}$ & $\begin{array}{c}\text { Shemil! makannya jangan banyak-banyak, } \\
\text { kamu udah overweight, jelek lo dek Shemil! }\end{array}$ & 2 \\
\hline 5 & $\begin{array}{c}\text { Teman kakak nggak mau } \\
\text { menjadi pengurus kelas }\end{array}$ & $\begin{array}{c}\text { Teman Nadya nggak mau menjadi pengurus } \\
\text { kelas, ya biar ajalah setiap orang kan punya hak } \\
\text { asasi }\end{array}$ & 3 \\
\hline 6 & $\begin{array}{c}\text { Nda, kakak takut kalau ayah } \\
\text { merokok terus, nanti ayah } \\
\text { sakit }\end{array}$ & $\begin{array}{c}\text { Nda, Nadya takut kalau ayah merokok terus, } \\
\text { paru-parunya rusak sehingga ayah sakit }\end{array}$ & 3 \\
\hline
\end{tabular}

Level kesantunan dari perubahan "beik/abbaik/labbaik" ujaran

ke уа.../уa...apa/ha..apa" mengalami perubahan pilihan kata dan berubahnya intonasi ketika melakukan tuturan. Pengaruh tindakan tutur pada teman sebaya pada usia pubertas juga terjadi pada perubahan berbahasa. Dari bahasa serapan beik/abbaik/labbaik yang semula menjadi konvensi bahasa khusus (keluarga) berubah menjadi bahasa ujaran umum (masyarakat dan teman sebaya). Perhatian Nadya yang lebih besar kepada teman-teman sebaya mempengaruhi cara ia bertindak tutur. Ujaran beik/abbaik/labbaik tidak lagi diucapkan secara konsisten, atau dengan kata lain mengalami perubahan. Termasuk intonasi ujaran yang berubah dari suara rendah ke suara agak meninggi. Level kesantunan ujaran ini mengalami perubahan dari level 3 (yang sopan) ke level 1 (kasar).

Tata cara berbahasa harus sesuai dengan unsur-unsur budaya yang ada dalam masyarakat tempat hidup dan dipergunakanya suatu bahasa dalam berkomunikasi. Apabila tatabahasa seseorang tidak sesuai dengan norma-norma budaya, maka akan mendapatkan nilai negatif, misalnya dijuluki sebagai orang yang sombong, tak acuh, bahkan tidak pandai bergaul.

Pada ujaran "Kakak sudah bilang, hati-hati dong dek", merupakan ujaran yang disampaikan Nadya kepada adiknya agar berhatihati. Dari tuturan tersebut Nadya menggunakan pronomina "kakak" untuk dirinya dan "adek/dek" untuk adiknya. Nadya memperlihatkan relasi yang tegas antara dirinya dan adiknya. Namun setelah menginjak masa pubertas awal, pronomina "kakak" dan "adek" tidak lagi ajeg 
digunakan. Dalam beberapa kali ujaran kalimat "Kakak sudah bilang, hati-hati dong dek" mengalami perubahan menjadi "Aku udah bilang, kamu hati-hati dong". Perubahan ujaran tersebut diantaranya: Pertama Pronomina "kakak" berubah menjadi " aku" dan pronomina "adek" berubah menjadi "kamu". Ini membuat makna peringatan Nadya terdengar lebih kuat "aku udah bilang, kamu hati-hati dong”. Dalam ujaran ini Nadya tidak lagi memperlihatkan garis pemisah antara adik dan kakak. Ia menggunakan pronomina "aku" dan "kamu" untuk memperlihatkan relasi yang setara dengan adiknya. Kedua, kata tambahan "dong" juga mengalami perubahan, semula terletak sebelum kata dek, berubah menjadi di akhir kalimat. Ujaran ini juga menunjukkan pada makna yang lebih kuat untuk mengingatkan kehati-hatian pada adiknya. Dari ujaran ini juga tersurat bahwa tindakan yang dilakukan Shemil diindikasikan oleh Nadya sebagai bagian tanggungjawabnya, bukan orang lain. Makna ujaran ini tampak berbeda dengan ujaran pertama yang lebih mengesankan adanya keinginan kakak untuk mengayomi adiknya. Dalam level kesantunan ujaran ini berada pada level 1, karena terdengar kasar dan tidak ada upaya untuk membangun hubungan emosional Nadya kepada adiknya. Namun pada sisi lain, peralihan pronomina yang berubah dari "kakak" ke pronomina "aku" dapat saja memberi makna solidaritas dan hubungan yang setara, karena melihat konteks persejawatan dengan adiknya. Hal ini dapat saja terjadi mengingat usia Nadya tidak terpaut jauh dengan adiknya, sehingga dalam situasi tertentu dapat saja ia merasa bahwa relasinya dengan adiknya sebagai seorang teman sebaya.

Begitu juga kalimat "kakak duluan ya dek" dan "Shemil aku duluan" juga terjadi perubahan, baik dari susunan struktur kalimat maupun pronomina. Pada kalimat pertama "kakak duluan ya dek" penutur lebih mengacu pada keinginan untuk mendapatkan persetujuan dari petutur (adik), sehingga penutur baru dapat melaksanakan tindakannya setelah mendapat persetujuan petutur. Kalimat kedua justru bermakna lain, penutur tidak lagi meminta persetujuan petutur, melainkan telah mengambil keputusan. Jadi ketika Ia mengucapkan "Shemil, aku duluan", penutur dapat melaksanakan tindakannya setelah ujarannya selesai. Berdasarkan analisis bahasa dan pikiran, ujaran Nadya tersebut dapat dimaknai dengan telah munculnya keberanian mengambil keputusan. Keberanian mengambil keputusan biasanya mengindikasikan adanya kemandirian dan tanggungjawab, yang menjadi sifat kedewasaan seseorang. Walau secara pikiran Nadya juga mengalami perubahan positif, namun pada level kesantunan berbahasa, perubahan bahasa Nadya berada pada level 2 karena tidak 
terlalu halus, tapi juga tidak terlalu kasar.

Kalimat "Dek makannya jangan banyak-banyak, kalo kegemukan nggak cantik dek" sering diucapkan Nadya bila melihat adiknya makan dengan lahap dan menyatakan keinginan untuk menambah makanan. Setelah menginjak masa pubertas awal, Nadya mengingatkan adiknya dengan perubahan bahasa sebagai berikut "Shemil! makannya jangan banyak-banyak, kamu udah overweight, jelek lo dek". Perubahan bahasa tersebut disamping terdengar lebih lugas, juga menggunakan peminjaman kata asing (borrowing), yaitu overweight. Kontak Nadya yang lebih luas misal melalui pertemanan dan pengaruh media, menjadi faktor yang dapat mempengaruhi tindak tuturnya, utamanya anak-anak yang mulai menginjak masa pubertas awal, senang menyelipkan beberapa kata asing dalam ujarannya. Di samping terlihat lebih gaul, peminjaman bahasa memberi kesan prestigius bagi penuturnya. Dilihat dari analisis bahasa dan pikiran (language and thought), Nadya telah membangun sebuah konsep "kecantikan", yaitu bertubuh langsing atau tidak kegemukan. Konsep itu menjadi tolak ukurnya, sehingga ia memperingatkan adiknya untuk tidak makan terlalu banyak agar memperoleh kecantikan berdasarkan cara pandangnya. Dari level kesantunan, perubahan bahasa Nadya berada pada level 1 , berbicara lebih spontan sehingga kedengaran lebih kasar, mengedepankan kata "jelek" ketimbang "tidak cantik".

Sedangkan pada kalimat "Teman kakak nggak mau menjadi pengurus kelas" adalah ungkapan bahasa yang rutin digunakan Nadya pada hari pertama setiap tahun ajaran baru. Setiap pemilihan pengurus kelas biasanya Nadya mendapat "langganan' dipilih dan ditunjuk menjadi salah satu pengurus; sekretaris, wakil, atau ketua kelas. Saat pertama kali Nadya menjadi murid baru di tingkat Tsanawiyah, tradisi pemilihan pengurus kelas dilakukan, dan Nadya terpilih menjadi wakil ketua kelas. Salah seorang temannya yang terpilih menjadi sekretaris kelas tidak siap dipilih dan menyatakan mengundurkan diri. Situasi itu diceritakan Nadya pada kedua orangtuanya. Kalimat "teman kakak nggak mau menjadi pengurus kelas", berubah menjadi "Teman Nadya nggak mau menjadi pengurus kelas, ya biar ajalah setiap orang kan punya hak asasi". Perubahan bahasa Nadya terjadi pada pergantian pronomina "kakak" menjadi "Nadya" dan tambahan argumen "ya biar ajalah setiap orang kan punya hak asasi”. Berdasarkan analisis bahasa dan pikiran, perubahan bahasa Nadya dari pronomina "kakak" ke "Nadya", dapat menunjukkan penegasan pada identitas diri yang lebih independen, tidak mengacu pada statusnya sebagai kakak, melainkan sebagai entitas dirinya sendiri. Begitu pula argumen tambahannya, ia menggunakan kata 
"hak asasi" sebagai konsep untuk menghargai pilihan dan keputusan orang lain. Penambahan usia dan pengetahuan bisa jadi mempengaruhi wawasannya, sehingga apa yang ia ungkapkan mencerminkan pola pikirnya saat itu. Level kesantunan kalimat ini dikategorikan pada level 3 karena dianggap lebih sopan dalam maknanya. Kata "hak asasi" menunjukkan negative politeness, formal, mengacu pada perbedaan, ketidaklangsungan sehingga tidak mengancam "muka" orang lain.

Perubahan bahasa lisan lainnya yang dapat peneliti rekam adalah kalimat, "Nda, kakak takut kalau ayah merokok terus, nanti ayah sakit". Seperti kalimat sebelumnya, perubahan bahasa disertai dengan tambahan argumen menjadi "Nda, Nadya takut kalau ayah merokok terus, paru-parunya rusak sehingga ayah sakit". Hampir sama dengan perubahan bahasa pada kalimat sebelumnya, perubahan bahasa yang terjadi pada kalimat ini juga terjadi pada pergantian pronomina "kakak" menjadi "Nadya". Nadya tidak lagi menggunakan pronomina penyapa "kakak, tapi langsung pada pronomina nama dirinya. Pergantian pronomina ini juga menunjukkan upaya untuk mempertegas identitas dan konsep diri, sebagai salah satu sikap dari anak-anak yang mengalami masa pubertas untuk mendapatkan pengakuan. Perubahan bahasa juga terjadi pada tambahan argumen. Argumen tersebut terbentuk bukan saja karena faktor lingkungan dan pendidikan anak, penambahan usia juga menjadi faktor yang mempengaruhi proses kematangan berpikir seseorang. Informasi yang diperoleh Nadya baik melalui bahan bacaan, media, iklan, atau sumber lain tentang bahaya merokok, mempengaruhi pikiran dan bahasanya. Di sini lah perubahan bahasa terjadi. Dengan demikian, perubahan bahasa bisa karena dipengaruhi oleh perkembangan pikiran anak, atau bisa jadi perkembangan pikirannya lah yang mempengaruhi bahasanya. Level kesantunan kalimat ini berada pada level 3 karena dikategorikan lebih halus. Tambahan argumen "Nadya takut kalau ayah merokok terus, paruparunya rusak sehingga ayah sakit" mengandung makna bahwa penutur menyuruh orang lain (dalam hal ini ayahnya) untuk tidak merokok. Strategi yang dipilih agar tidak menyinggung perasaan orang lain adalah dengan ungkapan "Nadya takut" dengan gaya merajuk. Selain itu kata "ayah sakit" merupakan bentuk solidaritas yang diperlihatkan penutur. Dengan strategi yang digunakannya ini, orang lain (ayah Nadya) bisa jadi berhenti merokok tanpa merasa "mukanya" terancam.

Selain itu ada dua jenis kesantunan yang menjadi perhatian saat kita berinteraksi dengan orang lain, yaitu positive politeness, yang mengarah ke peningkatan solidaritas, ditandai dengan penggunaan bahasa 
yang informal, menawarkan pertemanan, dan penggunaan pujian. Negative politeness mengarah kepada pembedaan, penggunaan bahasa yang formal, dan ketidaklangsungan.

Beberapa bahasa dibangun ke dalam sistem kesantunan yang pelik. Bahasa Jawa misalnya menurut Geerts (1960), hampir tidak mungkin untuk mengatakan apapun tanpa mengindikasikan hubungan sosial antara pembicara dan pendengar dalam hal status dan kekeluargaan. Sebelum orang Jawa berbicara dengan yang lainnya dia harus memutuskan ragam ujaran yang berterima : ragam tinggi, menengah, atau rendah.

Dalam beberapa bahasa, pronomina tertentu mengindikasikan makna dalam kesantunan. Misal bahasa Prancis, membedakan pronomina $T u$ dan Vous. Bentuk $T u$ kadang-kadang digambarkan sebagai sebuah bentuk yang 'familiar' dan bentuk Vous sebagai sebuah bentuk yang 'sopan.

Konsekuensi dari penggunaan dua pronomina itu adalah pada abadabad pertengahan saat orang-orang kelas atas mulai saling menggunakan pronomina Vous untuk menunjukkan saling menghormati dan rasa kesantunan. Walau demikian pronomina $T u$ masih dipertahankan, dan orang-orang kelas bawah saling menggunakan bentuk hubungan $T u$, dan orang-orang kelas atas menunjuk orang-orang di kelas lebih rendah dengan $T u$ tetapi menerima Vous. Oleh karena itu penggunaan tanda yang asimetris ini menghadirkan sebuah lambang kekuatan hubungan persaudaraan dan persahabatan.

Bentuk simetris penggunan Vous menjadi penggunaan yang sopan. Penggunaan yang sopan ini kemudian menyebar di kalangan masyarakat, tetapi tidak semua lapisan, jadi hanya dalam kelas-kelas tertentu saja, tetapi tidak pernah samapi pada kelas yang lebih rendah, kecuali antara suami dan isteri, orang tua dan anak, dan para pecinta. Bentuk simetris penggunaan $T u$ selalu berusaha untuk menunjukkan sebuah hubungan kedekatan (keintiman). Oleh karena itu penggunaanya merujuk pada situasi-situasi di mana dua pihak setuju bahwa mereka memiliki ketertarikan-ketertarikan yang umum seperti solidaritas.

Dalam bahasa Indonesia, penggunaan pronomina $T u$ dan Vous, belum sangat tegas perbedaannya. Namun berdasarkan konteks komunikasi tertentu, penggunaan pronomina tertentu dapat menunjukkan sebuah pemaknaan yang dapat mengarah pada kesantunan pada satu sisi, atau solidaritas pada sisi lain.

\section{E. SIMPULAN}

a. Perubahan bahasa masa pra-pubertas mengalami peralihan karena faktor usia dan relasi yang dibangun penutur pada masa pasca pubertas. Perubahan bahasa terjadi karena faktor eksternal dalam keajekan menggunakan bahasa serapan (dalam kasus penelitian ini 
adalah serapan bahasa Arab) bergeser bahkan hilang . Semakin bertambahnya usia dan hubungan sosial keajekan bahasa seseorang menjadi longgar.

b. Bahasa anak yang mengalami masa transisi bersifat resiprokal dengan pikirannya. Karenanya bahasa pada masa pasca pubertas dapat mempengaruhi pikiran dan pikiran juga dapat mempengaruhi perubahan bahasa seseorang.

c. Kesantunan bahasa anak pada masa pasca pubertas tidak dapat dilihat melalui norma kesantunan semata tapi juga harus melihat faktor solidaritas bahasa teman-teman sebaya bagi penutur dan petutur dalam prinsip kerjasama tuturan.

\section{DAFTAR PUSTAKA}

Brown, Penelope and Stephen C.

Levinson. Politeness: Some

Universals in Language Usage.

Cambridge: Cambridge

University, 1978, h.61.

Holmes, Janet. 1994. An Introduction to Sociolinguistics. London and New York: Longman.

Malibary, Ahmad Akrom. 2007. At-

Taghayyur al-Dalali:

Anwâ'uhu, Simâtuhu,

Asbâbuhu, Asykâluhu, dalam

Âfâq 'Arabiyyah: Jurnal

Pendidikan Bahasa Arab.

Jakarta: Fakultas Ilmu Tarbiyah dan Keguruan (FITK) UIN

Syarif Hidayatullah Jakarta.
Muslich, Masnur. "Kesantunan

Berbahasa: Sebuah Kajian

Sosiolinguistik", http://re-

searchengines.com/1006masnur

2.html, diunduh tanggal 29 Juli

2009.

Leaner, Richard M. dan Graham B.

Spanier. 1980. Adolescent

Development A Life-Span

Perspecive. New York:

McGraw-Hill Company.

Searle, John R. 1969. Speech Acts:

An Essay in the Philosophy of

Language,Cambridge:

Cambridge University.

Vilkki, Liisa. 2013. "Politeness, Face and Facework: Current Issues", dalam A Man of Measure

Festchrift in Honour of Fred

Karlsoon, akses tanggal 29

Maret 2013.

Wardhaugh, Ronald. 2006. An Introduction to Sociolinguistics.

Victoria: Blackwell Publishing.

Zahran, Hamid Abdussalam. 1986.

Ilmu Nafsin Numuwwuw. Kairo:

Dar al-Ma'arif. 
